\title{
LA FISCALÍA ESPAÑOLA, ¿DEBE SER UNA INSTITUCIÓN INDEPENDIENTE?
}

\author{
JUAN-LUIS GÓMEZ COLOMER \\ Catedrático de Derecho Procesal \\ Universidad Jaume I de Castellón
}

\section{SUMARIO}

I. Introducción. II. La Fiscalía General del Estado, ¿orgánicamente dependiente del Gobierno, o independiente? III. El Ministerio Fiscal en el proceso penal, ¿funcionalmente instructor y parte acusadora, o sólo parte acusadora? IV. Conclusiones.

\section{INTRODUCCIÓN}

Trato a continuación dos temas relativos al Ministerio Fiscal español que, además de gozar de una gran actualidad, se suelen presentar separados, pero que tienen más relación entre sí de lo que se piensa: El primero afecta a los principios básicos de organización de la Fiscalía en España, más en concreto, a si el Ministerio Fiscal como institución pública es, o mejor, si debe ser independiente; el segundo; a si la configuración orgánica que hayamos decidido al tratar el aspecto anterior tiene como consecuencia funcional que el Ministerio Fiscal no instruya, $o$, al contrario, sí deba instruir, la fase preparatoria del proceso penal dirigiendo la investigación procesal del crimen e instruyendo formalmente las causas criminales.

Ambas cuestiones, la orgánica y la funcional, están en mi opinión estrechamente relacionadas. No descarto por ello una visión constitucional, clara en España por otra parte, en el sentido que la Fiscalía es una institución procesalmente omnipresente en todos los órdenes jurisdiccionales y ante todos los Tribunales reconocidos por la Constitución (con excepción de los consuetudinarios), porque en todos ellos debe defender la legalidad y velar por el respeto a los derechos de los ciudadanos, de acuerdo con el art. 124 de la Constitución española —en adelante abreviada CE— de 1978. 
Tampoco descarto algún apunte de Derecho comparado, con una posición mayoritaria diáfana en los países de nuestro entorno cultural como se verá infra, para una mejor comprensión.

Estos temas están afectando a la Fiscalía española de manera insistente, provocando turbulencias severas, pues a día de hoy ciertos sectores la contemplan como órgano político y no quieren que lo sea, y le están dando avisos de que le va a tocar instruir el proceso penal, que no acaban de concretarse, siendo posible imaginar que tampoco quiera hacerlo.

Pero vayamos por partes. Ante todo, caracterizan legalmente a la Fiscalía española los siguientes aspectos:

$1^{\circ}$ Es un órgano constitucional (el art. 124 CE, y el art. 2.1 del Estatuto Orgánico del Ministerio Fiscal —en adelante abreviado EOMF- de 1981, lo califican como órgano «de relevancia constitucional»).

$2^{\circ}$ Es un órgano jurídico, porque como hemos visto tiene como misión principal constitucional defender la legalidad.

$3^{\circ}$ Además de ser un órgano jurídico, hay base jurídica suficiente para considerar también una cierta naturaleza política en la institución. Obviamente, no nos referimos a que la Fiscalía haga política o a que participe del juego político democrático. Esto es inimaginable en España. Muy al contrario, si lo calificamos de parcialmente político es porque, aunque goce de «personalidad jurídica propia» y se integre en el Poder Judicial «con autonomía funcional» (frase poco clara del art. 2.1 EOMF, que entiendo se refiere a marcar la distinta naturaleza por la función del Fiscal respecto al Juez), su jefe, el Fiscal General del Estado, es nombrado por el Rey a propuesta del Gobierno (art. 124.4 CE), eligiéndose entre juristas españoles de reconocido prestigio con más de quince años de ejercicio efectivo de su profesión (art. 29.1 EOMF). Y ello hace que la esencia de la institución — su origen — sea de naturaleza política y nadie puede negarlo, creo honradamente que ni siquiera se puede discutir.

$4^{\circ}$ Goza de dos legitimidades democráticas, pero ciertamente taimadas: Se requiere previo al nombramiento del Fiscal General del Estado un informe del Consejo General del Poder Judicial, no vinculante (art. 124.4 CE); y debe someter su programa de actuación por 4 años al Congreso de los Diputados, que valora los méritos e idoneidad del candidato (arts. 29 y 31.5 EOMF). No es anecdótico que, una vez nombrado y prestado juramento o promesa ante el Rey, tome posesión de su cargo ante el Pleno del Tribunal Supremo (art. 29.3 EOMF).

$5^{\circ}$ Constituye una administración autónoma, con órganos propios, organizada conforme a los principios de unidad de actuación y de dependencia jerárquica (art. 124.2 CE), incardinada presupuestariamente en el Ministerio de Justicia (v. por ejemplo, art. 72 y DA-2 $2^{\mathrm{a}} \mathrm{EOMF}$ ), órgano político que conoce de los recursos en la vía previa administrativa (art. 67.3 EOMF), y que además —el Gobierno a su través- desarrolla reglamentariamente el Estatuto propio (DF- $1^{\mathrm{a}} \mathrm{EOMF}$ ).

$6^{\circ}$ El Ministerio Fiscal actúa con sujeción a la Constitución, a las leyes y demás normas que integran el ordenamiento jurídico vigente (principio de 
legalidad), y con plena objetividad e independencia en defensa de los intereses que le estén encomendados (principio de imparcialidad), en el ejercicio de sus funciones (arts. 6 y 7 EOMF). El término «independencia» aplicado a la Fiscalía es perturbador y es uno de los que provoca la discusión que vamos a tratar enseguida.

$7^{\circ}$ Cada órgano jurisdiccional tiene atribuida una fiscalía, desde el más ínfimo al más alto, tanto si se trata de un órgano ordinario como especial (Tribunal Constitucional, Tribunal de Cuentas y tribunales militares especialmente).

$8^{\circ}$ El Gobierno, y en especial el Presidente del Gobierno, puede ordenar al Fiscal General del Estado determinada actuación en defensa del interés público (por ejemplo, persecución penal, acusación, o petición de sobreseimiento), y éste debe obedecerla, bien directamente, bien trasladando la orden al Fiscal del caso (art. 8 EOMF). Es cierto que la literalidad afirma que: «El Gobierno podrá interesar del Fiscal General del Estado que promueva ante los Tribunales las actuaciones pertinentes en orden a la defensa del interés público», por tanto, no habla de ordenar, sino de «poder interesar», pero en la práctica hasta ahora cuando el Estado ha interesado del Fiscal General del Estado una actuación, éste ha cumplido el interés como si fuera una orden ${ }^{1}$.

Esta norma es otra de las que provoca que para una opinión muy fundada la configuración de la Fiscalía española sea clara, en lo que afecta a su cúpula al menos, la Fiscalía General del Estado: Órgano políticamente dependiente del Gobierno ${ }^{2}$.

$9^{\circ}$ Y el Fiscal General del Estado, por el principio de jerarquía, puede impartir a sus subordinados las órdenes e instrucciones que fueren convenientes al servicio y al ejercicio de las funciones, tanto de carácter general como referidas a asuntos específicos (art. 25, I EOMF). También puede avocar asuntos y sustituir a fiscales designados si se cumplen las limitaciones legales establecidas en el art. 23 EOMF.

$10^{\circ}$ La corrección jurídica de la orden del Gobierno debe ser analizada por la Junta de Fiscales de Sala: El Fiscal General del Estado, oída la Junta de Fiscales de Sala del Tribunal Supremo, resolverá sobre la viabilidad o procedencia de las

1 Lo he podido comprobar en una investigación muy compleja sobre un delito ecológico muy grave al norte de mi tierra: El Gobierno «instó» a la FGE la no persecución de una parte imputada (un empresario clave en la economía española), y el Fiscal del caso sumisamente «acató» la instancia que le trasladó su superior. Por cierto, esa «instancia» nunca apareció en la documentación de la causa. Vid. Gómez Colomer, J.L. / Esparza Leibar, I., La persecución procesal penal del delito ecológico. Análisis de un caso real, Els Ports et alii versus Endesa, Tirant lo Blanch, Valencia 2009, pág. 43. Y hay muchos casos más, que por ser públicos y notorios, no hace falta citar aquí.

2 Y ha motivado que, aunque aquí se refiere a la lucha contra la corrupción, el Grupo GRECO del Consejo de Europa haya propuesto, en su «Fourth Evaluation Round. Corruption prevention in respect of members of parliament, judges and prosecutors», Interim Compliance Report Spain, de 3 de enero de 2018, Recomendación IX, numeral 63, pág. 10, publicado en https://rm.coe.int/fourth-evaluation-round-corruption-prevention-in-respect-of-members-of/1680779c4d, para garantizar una mayor autonomía de la Fiscalía, que las relaciones entre el Gobierno y el Fiscalía General del Estado se realicen de una manera transparente, por escrito y con una publicidad adecuada. 
actuaciones interesadas y expondrá su resolución al Gobierno de forma razonada (art. 8.2, II EOMF). De modo que en teoría la orden del Gobierno puede ser rechazada.

$11^{\circ}$ Es cierto que ningún fiscal está obligado a cumplir una orden ilegal del Fiscal General, ni mucho menos órdenes externas a la propia Fiscalía, por ejemplo, del Ministro de Justicia (v. arts. 27 y 55, II EOMF), sometiéndose al procedimiento interno establecido en esa norma para no obedecerla.

$12^{\circ}$ El Fiscal es co-jefe de la Policía Judicial, junto con el Juez Instructor (art. 126 CE y art. 4.4 EOMF, a los que hay que sumar las pertinentes disposiciones de la Ley Orgánica 2/1986, de 13 de marzo, de Fuerzas y Cuerpos de Seguridad y normas complementarias).

$13^{\circ}$ Finalmente, el Fiscal en España no instruye el procedimiento preliminar judicial (salvo excepciones que veremos más adelante, poco relevantes atendido el conjunto del sistema, pues es competencia de un órgano judicial, el Juez Instructor, sino que es parte acusadora promoviendo la acción de la justicia en defensa de la legalidad (art. 124.1 CE), aunque con ciertas ventajas importantes respecto a las partes acusadoras no públicas si las hubiere (la víctima como acusadora particular; y el español no ofendido por el delito, como acusador popular, art. $125 \mathrm{CE}$ ). En su concreción, ejercita «las acciones penales y civiles dimanantes de delitos y faltas» (éstas suprimidas por la Ley Orgánica 1/2015, de 30 de marzo), o se opone «a las ejercitadas por otros, cuando proceda» (art. 3.4 EOMF).

\section{LA FISCALÍA GENERAL DEL ESTADO, ¿ORGÁNICAMENTE DEPENDIENTE DEL GOBIERNO, O INDEPENDIENTE?}

A la vista de estas trece características de la Fiscalía española, debemos abordar la primera cuestión: ¿Es independiente la Fiscalía española del Gobierno? Si no lo es, ¿debe serlo?

Ante todo, debo precisar dos cuestiones importantes:

Primera, que me centro en el ámbito penal de la Fiscalía española. No ignoro los demás ámbitos, pero la mayor trascendencia está en el orden jurisdiccional penal, y a él dedico mi reflexión.

Segunda, debo explicar igualmente qué entiendo por independiente en esa pregunta. El art. 124.2 CE y el art. 2.1 EOMF dicen que la Fiscalía debe actuar conforme al principio de imparcialidad, y la imparcialidad es la nota esencial de la Jurisdicción, del Poder Judicial, en suma, del Juez. Por eso la propia Constitución no ha predicado del Fiscal la independencia, y en cambio sí lo ha hecho del Juez (art. 117.1 CE). Sin embargo, el art. 7 EOMF dice que «por el principio de imparcialidad el Ministerio Fiscal actuará con plena objetividad e independencia en defensa de los intereses que le estén encomendados.»

Esto es un error grave. En efecto, si por independencia entendemos la sujeción del juez únicamente a la ley, y por imparcialidad la posición de ajenidad 
respecto al conflicto entre las partes (Estado y acusado) provocado por el delito, el Fiscal no es independiente, ni puede serlo nunca. Primero, porque, aunque el Fiscal esté sometido al principio de legalidad, el interés público le permite una interpretación amplia respecto a la ley aplicable escogiendo aquella que sea más favorable a su posición, y segundo porque al ser parte acusadora, no puede ser imparcial, sino que debe ser parcial, promoviendo la acción de la justicia en defensa de la legalidad, o lo que es lo mismo en el caso del proceso penal, acusando como parte actora ${ }^{3}$. La independencia por tanto, queda reservada al Poder Judicial como su característica más esencial, de hecho como principio básico de su constitución, y nunca al Ministerio Fiscal.

Otra cosa es que el Fiscal sea objetivo, esto nada tiene que ver con la independencia, y es predicable de cualquier funcionario público (art. 103.1 CE)

La doctrina que afirma que el Fiscal es independiente, recogida en nota en este escrito, contraargumenta afirmando que:

a) No hay que confundir al Fiscal General del Estado con los Fiscales, pues aquél es de designación política, pero éstos no y, por tanto, son independientes. Se separa por tanto al Fiscal General del Estado (art. 12, a) EOMF) de los demás Fiscales a él subordinados (arts. 22 y 23 EOMF), porque el jefe no es el único representante, representantes lo son todos. De esta manera, el carácter político no afecta a los Fiscales, sólo al Fiscal General del Estado. Pero en tanto exista una posibilidad de que el Fiscal General pueda transmitir un interés del Gobierno para que se cumpla, el riesgo existe, es evidente, y se trata de que no exista.

b) Que hay una dependencia ad intra, es decir, en su organización funcional al estar sometidos al principio de jerarquía, y otra ad extram, en su actuación diaria ante los tribunales, en la que prima la legalidad. Conforme a ella, el Fiscal, todos los fiscales, son independientes porque en relación con el caso concreto se está en posición de ajenidad, de manera que qué posición procesal ocupe el fiscal no es determinante de la imparcialidad. Pero esto en realidad califica la imparcialidad, no la independencia.

c) Que los Fiscales están sometidos como los jueces al mandato legal y solamente a la ley. Sí, pero con una diferencia esencial: No deciden conflictos con carácter irrevocable. Por tanto, el concepto no es el mismo, porque también los funcionarios de la Administración están sometidos sólo a la ley, aunque ciertamente, también de forma distinta los funcionarios a los fiscales, porque no es lo mismo actuar legalmente que defender la legalidad (v. art. 103.1 CE, y art. 1.2, c) de la Ley 7/2007, de 12 de abril, del Estatuto Básico del Empleado Público).

Son argumentos importantes, pero discutibles (como en realidad lo es todo el Derecho, probablemente su principal atractivo), y alguna crítica hemos

3 Las Directrices sobre la Función de los Fiscales, aprobadas en el Octavo Congreso de las Naciones Unidas sobre Prevención del Delito y Tratamiento del Delincuente, celebrado en la Habana en 1990, nunca hablan de independencia del Fiscal, sino de imparcialidad. 
formulado ya. Debe quedar claro que no estoy pensando en las Circulares, Instrucciones y Consultas que emite la Fiscalía General del Estado, perfectamente legales, porque favorecen internamente una posición coherente de la Fiscalía en todos los casos y porque no vinculan al juez en sus decisiones cuando el Fiscal las alega en su argumentación ${ }^{4}$.

En ningún caso se pretende afirmar que el Fiscal, al no ser independiente, pueda ser arbitrario, injusto o autoritario, o que pueda actuar impunemente de esta manera, en absoluto. Su sujeción al principio de legalidad debe garantizar, y estoy seguro que garantiza en la práctica, que el trabajo de los Fiscales sea el que la Sociedad espera: Justo, objetivo, equilibrado y ajustado a la legalidad. Pero los Fiscales no deciden, sino que instan la decisión, que sólo corresponde a los Jueces, con lo cual el concepto «independencia» les debe ser necesariamente ajeno, y si esto parece demasiado radical, que no lo es, estamos al menos manejando dos conceptos de independencia, lo que no es procesalmente fructífero porque genera confusión.

Por tanto, en mi opinión, el concepto de independencia que aquí estoy usando se refiere exclusivamente a la posición de sujeción a la ley de un órgano público como único fin de su actividad. En este sentido la Fiscalía española ni es, ni debe ser independiente, pues, aunque esté sujeto a la legalidad vigente, la aplicación de la Política Criminal del Estado ${ }^{5}$, le permite ladear límites mucho más amplios y difusos (por ejemplo, no acusar existiendo delito, por aplicación del principio de oportunidad reglada, que por serlo implica sometimiento a la legalidad, pero que esencialmente conlleva una buena dosis de discrecionalidad).

Esta opinión queda reforzada al observar cómo se ha resuelto el tema de la dependencia jerárquica ente el Gobierno y la Fiscalía. Ya lo hemos apuntado (art. 8 EOMF): El Gobierno, y también el Presidente, pueden instar al Fiscal General cualquier actuación basada en el interés público, que generalmente coincide con el interés social. Éste sólo puede negarse a cumplirla si su Junta de Fiscales entiende que es incorrecta jurídicamente. Esta posibilidad no negaré que sea real ${ }^{6}$, pero pensar que vaya a ocurrir es casi una ingenuidad, además de ser estadísticamente

4 Tampoco estoy pensando en la «orden» del art. 956 LECRIM, porque nada tiene que ver con lo que estamos tratando y además está en desuso por no corresponderse con la reforma de la revisión de 1992. El Ministerio se limita hoy a solicitar opinión y el Fiscal a darla. La legitimación es ahora la del art. 955 LECRIM.

5 Sin entrar en detalles, es muy difícil observar una Política Criminal clara y coherente en los Gobiernos de la democracia en España, porque no se expone como tal. Si por Política Criminal entendemos las razones que hay detrás de cada Ley, eso no es Política, sino motivación singularizada. Con lo cual difícilmente se puede afirmar con seriedad que la Fiscalía ejecuta la Política Criminal del Gobierno, aunque teóricamente sea correcto. Vid. Díez Ripollés, J.L. La racionalidad de las leyes penales, Práctica y teoría (2a ed.), Trotta, Madrid 2013, págs. 18 y ss.; y, del mismo autor, La política criminal en la encrucijada, BdeF, Buenos Aires 2007, págs. 79 y ss.

6 Se solicitó a mitad de 2017 la desobediencia del Fiscal General del Estado a una orden del Ministerio de Justicia, ante la improvisada implantación del proyecto papel-cero para la Administración de Justicia, al considerar las dos asociaciones de fiscales principales en España que todavía no se estaba preparado para la 
irrelevante. ¿Cree alguien de verdad que el extenso equipo de juristas y asesores que tiene el Ministerio de Justicia va a avalar que el Gobierno formule una petición al Fiscal General jurídicamente incorrecta, es decir, ilegal?

O sea, parece que sí pero no, aunque no se engañen, es que sí, a saber y con todos los matices que se quieran, el Fiscal español es (sin duda en lo penal) dependiente políticamente del Gobierno.

Hay otra razón más profunda, dogmáticamente irreprochable, que hace referencia a todo el sistema. Pero antes de entrar en ella me permitirán que les ofrezca ahora un apunte de Derecho comparado, centrándome en los países de mayor influencia jurídico-procesal penal en España, para que no nos rasguemos farisaicamente las vestiduras, en donde se verá que en ningún país de los que influyen en nuestra legislación, salvo Italia, la Fiscalía es independiente ${ }^{7}$. Insisto en que me centro en la jurisdicción penal:

\section{A) Alemania}

La principal autoridad acusadora, única en la mayoría de los casos, en el proceso penal alemán es el Ministerio Fiscal, órgano jerárquicamente estructurado (no independiente), cuyos miembros deben acatar las órdenes propias del servicio de su superior ( $\$ 146$ de la Ley Orgánica del Poder Judicial alemana —abreviada GVG-), actuando en representación del primer funcionario de la Fiscalía, en el caso de existir varios miembros $(\S 144 \mathrm{GVG})^{8}$.

El Ministerio Fiscal, la Fiscalía, es una autoridad de la Administración de Justicia, una autoridad autónoma dentro de la misma?

Su origen es propio, pues nace en el siglo XIX en Prusia, no por influencia francesa, sino para que el Poder Político pudiera controlar a los jueces en la aplicación de la ley, cuya arbitrariedad en muchas ocasiones era manifiesta, permitiendo,

Justicia digital y que el Fiscal General actuaba en este tema, que había paralizado la Justicia, como un cargo sumiso al Ministerio de Justicia. No prosperó. Puede verse en la prensa posterior al 10 de julio de ese año.

7 Han estudiado el aspecto comparado: Conde-Pumpido Ferreiro, C., El Ministerio Fiscal, Aranzadi, Pamplona 1999, págs. 21 y ss.; MarChena Gómez, M., El Ministerio Fiscal: Su pasado y su futuro, Ed. Marcial Pons, Madrid 1992, págs. 43 y ss.; Martínez Dalmau, R., Aspectos constitucionales del Ministerio Fiscal, Ed. Tirant lo Blanch - Universitat de València, Valencia 1999, págs. 51 y ss.; López López, A.M., El Ministerio Fiscal español. Principios orgánicos y funcionales, Ed. Colex, Madrid 2001, págs. 25 y ss.

8 No es autoridad judicial porque el ejercicio de la función jurisdiccional no le viene reconocido por el art. 92 de la Constitución alemana -abreviada GG-, por la sujeción jerárquica a las disposiciones del superior, y por la falta del efecto de cosa juzgada en sus resoluciones, v. Roxin, C. / SchünemanN, B., Strafverfabrensrecht (29a ed.), C.H. Beck, München 2017, pág. 56. Prescindimos de referencias bibliográficas concretas con relación a la figura del Fiscal alemán, por no ser necesarias dadas las características de esta aportación. Vide en ese libro citado las págs. 52 y 53 para una profundización adecuada.

9 Sobre la historia de este órgano en Alemania, v., breve pero claramente, ZIPF, Strafprozeßrecht (2 $2^{\mathrm{a}}$ ed.), Walter de Gruyter, Berlin-New York 1977, págs. 42 a 44. Extensamente, ScHMIDT, Einführung in die Geschichte der deutschen Strafrechtspflege ( $3^{\mathrm{a}}$ ed.), Vandenhoeck \& Ruprecht, Göttingen 1995, págs. 330 a 332. 
por ejemplo, que el Fiscal pudiera recurrir sus decisiones de sobreseimiento o sus sentencias ante tribunales superiores. Hoy, la organización de la Fiscalía alemana depende en buena parte de ser Alemania un Estado federal, como es lógico, lo que marca particularidades y diferencias importantes con otros sistemas jurídicos, entre los que se encuentra el español. Interesa a nuestros efectos destacar las siguientes cuestiones organizativas del Ministerio Fiscal alemán ${ }^{10}$ :

a) Los Fiscales en Alemania han de tener la misma capacidad que se exige para ser Jueces (\$ 122, ap. 1 de la Ley de los Jueces alemanes —abreviada DRiG—), pero no pertenecen al Poder Judicial, del que son independientes ( $\$ 150 \mathrm{GVG}$ ), ni pueden realizar ninguna de las tareas que la Ley encomienda a los Jueces $(§ 151$ GVG).

b) Los Fiscales son funcionarios públicos ( $\S 144$ y 148 GVG), razón por la que no gozan de los principios políticos propios del Poder Judicial, básicamente no son independientes, como indicamos supra, estando obligados a seguir las órdenes del Fiscal superior ( $\$ 152 \mathrm{GVG}$ ).

c) Con base en la jerarquía antedicha, la Fiscalía constituye una autoridad organizada del siguiente modo: En Alemania el Jefe superior es el Fiscal General Federal. De acuerdo con el $\S 149$ GVG, es nombrado por el Presidente de la República a propuesta del Ministro Federal de Justicia, en realidad es propuesta de todo el Gobierno encabezado por su Bundeskanzler. Es necesaria la previa aprobación del nombramiento por el Senado - Bundesrat_- El Gobierno puede cesar al Fiscal General Federal ${ }^{11}$. Su naturaleza claramente política es compensada con la gran confianza pública que existe en la institución.

d) El Fiscal General Federal es quien actúa como Fiscal ante el Tribunal Supremo Federal, en donde cuenta con la ayuda de varios Fiscales Federales; siguen los Fiscales de los Tribunales Superiores del Land, con su jefe a la cabeza; y los Fiscales de los Tribunales del Land, también con su propio jefe de la Fiscalía; además, para finalizar, existen los Fiscales de los órganos judiciales inferiores ( $\S 142$ y 142 a GVG). Su estructura responde, por tanto, como es lógico, a la de los Juzgados y Tribunales alemanes, pues de acuerdo con el $\S 141$ GVG, ante cada Tribunal deberá existir una Fiscalía, incluso con conexión territorial entre $\operatorname{ambos}(\S 143 \mathrm{GVG})^{12}$.

e) El Fiscal General Federal no es sólo un cargo político que preside una organización administrativa, sino que también debe ejercer la acción pública en

10 No sólo estatal, sino también de los Länder, v. \$§ 141 a 152 GVG, y, sobre ellos, Wolf, Gerichtsverfassungsrecht aller Verfabrenszweige (6 ${ }^{a}$ ed.), C.H. Beck, München 1987, págs. 293 y ss., y PETERs, Strafprozeß ( $4^{\mathrm{a}}$ ed.), C.F. Müller, Heidelberg 1985, págs. 160 y ss.

11 Y recientemente así ha sucedido. El día de 4 de agosto de 2015 la Bundedskanzlerin Dr. Angela Merkel ha cesado al Fiscal General Federal Dr. Harald Range, por fuertes desavenencias en una investigación por alta traición de un blog periodístico.

12 Véase Nieva Fenoll, J., «El Ministerio Fiscal en Alemania», Revista Justicia 99, núm. III-IV, págs. 595 y ss. 
caso de haberse producido uno de los graves hechos punibles señalados en el $\S$ 142a GVG, v.gr., delitos contra los órganos constitucionales del Estado, traición, etc., por tanto, con obligaciones funcionales específicas (v. § 145 GVG).

Tampoco es una autoridad administrativa pura, porque su actividad no se deriva de las exigencias de la Administración, no está orientada hacia las mismas, sino hacia la Verdad y Justicia.

\section{B) Italia}

El caso italiano es distinto al español y al alemán (en realidad a todos los demás, porque es único). Los fiscales son magistrados, pero no son Poder Judicial. Jueces y fiscales forman parte del mismo cuerpo, tienen el mismo estatuto jurídico y ambos son gobernados por el Consiglio Superiore della Magistratura (art. 107 de la Constitución italiana —en adelante CI — de 1947), que es presidido por el Presidente de la República (art. 104 CI) ${ }^{13}$.

Pero que magistratura y fiscalía estén desde el punto de vista orgánico unificados no significa que se confundan sus roles procesales, pues las funciones son lo que distingue a ambas. Si se tiene capacidad constitucional de juzgar, se es juez, es decir, Poder Judicial; si no se tiene la facultad constitucional de juzgar, sino de instar el juzgamiento, entonces se es fiscal, es decir, Pubblico Ministero. Por eso se habla de Magistratura decidente (el juez), y de Magistratura requirente o postulante (el fiscal). El paso de una función a otra está regulado en el art. 190 de la Ley del Ordenamiento Judicial de 1941, reformado en 1988.

Bajo esta organización no es posible la existencia de un Fiscal General de la República nombrado por el Gobierno, ni por el Parlamento. No existe en consecuencia en Italia esta figura, lo que de entrada significa que los peligros de su jerarquización son menores. Y, por tanto, que el fiscal italiano no tiene ninguna posibilidad de ser influenciado por el Gobierno en el ejercicio de la acción penal.

El Fiscal es autónomo en el ejercicio de sus funciones (no independiente). La Policía Judicial depende de él (arts. 57 y 59.3 del Código Procesal penal —abreviado CPP_, art. 11 Ley 1 abril 1981 sobre organización de la administración de la seguridad pública).

Cada tribunal tiene su Fiscalía, desde el mayor al menor de ellos: Fiscalía ante el Tribunal de Casación, Fiscalía ante los Tribunales de Apelación, y Fiscalía ante los Tribunales ordinarios. Todos ellos son nombrados por el Consiglio Superiore.

13 Véanse Biavati, P. / Guarneri, C. / Orlandi, R. / Zanon, N., La giustizia civile e penale in Italia, Il Mulino, págs. 126 y ss. Villagómez, M., «El nuevo proceso penal italiano», Documentación Jurídica, núm. 61, Ministerio de Justicia, Madrid 1989, págs. 17 y 18. 


\section{C) Francia}

Cabe el honor a Francia de haber sido el país que diseñó la figura del Ministerio Fiscal como lo conocemos en la Europa continental, en verdad desde la Revolución Francesa hasta prácticamente la actualidad (por lo menos en España). El Fiscal nace como figura del Estado encargada de vigilar el cumplimiento de la legalidad, especialmente por parte de los jueces en la recién instaurada división de poderes.

Es por tanto un órgano político, instaurado en el Poder Ejecutivo (dependiente del Ministerio de Justicia), creado por él para vigilar a otro poder.

La Ley de 16 al 24 de agosto de 1790, Tít. VIII, art. 1, desarrolló este modelo de Fiscal y le atribuyó la acusación penal pública, teniendo una influencia decisiva en toda Europa, no sin altibajos y momentos críticos ${ }^{14}$.

Los magistrados (magistrats du siège) y los fiscales (magistrats du parquet) forman parte del mismo cuerpo, gozando del mismo estatuto jurídico, como más tarde se va a desarrollar en Italia, distinguiéndose sólo por las funciones. El Fiscal francés es un fiscal que goza de autonomía, pero al que el Gobierno puede ordenar determinadas actuaciones en función de los intereses generales. El jefe ante cada tribunal es un Procurador General o un Procurador de la República, que son sustituidos y representados en su quehacer diario por abogados fiscales. Todos dependen jerárquicamente del Ministerio de Justicia.

\section{D) Estados Unidos}

En USA existe Fiscal General, pero no es una figura autónoma, sino que se inserta en el Gobierno federal como Ministro de Justicia (Secretario del Departamento de Justicia Federal), por tanto, como cargo nombrado discrecionalmente por el Presidente del país (Judiciary Act de 1789). ${ }^{15}$

De él dependen los Fiscales Jefes, también nombrados por el Presidente de los Estados Unidos, previa autorización del Senado, y de éstos los Fiscales federales.

En los estados existen los fiscales estatales, de distrito y de condado, generalmente elegidos democráticamente. Por eso existe una gran movilidad e interinidad en su trabajo.

El Fiscal goza del monopolio de la acción penal y de un gran poder discrecional en la investigación del crimen, lo que implica que en el desarrollo de su trabajo goza de una autonomía remarcable. Esto es importante, porque es consustancial al modelo anglosajón de enjuiciamiento criminal, el llamado sistema adversarial,

14 Madrid Boquín, C., «La ¿independencia? del Ministerio Fiscal y su relación con los Poderes del Estado», en La independencia del Ministerio Fiscal, Colección Jóvenes Juristas, vol. 1, Astigi, Sevilla 2018, en prensa.

15 Gómez Colomer, J.L. (Coord.), Introducción al proceso penal federal de los Estados Unidos de Norteamérica, Tirant lo Blanch, Valencia 2013, págs. 159 y 160. 
que el Fiscal se visualice como el representante del Gobierno en el proceso defendiendo los intereses de la comunidad, de la misma manera que el Jurado se visualiza como el defensor del acusado frente a injerencias públicas intolerables en sus derechos fundamentales.

De esta manera no hay debate, porque se considera absurdo discutir sobre si el Fiscal General debe ser nombrado de manera distinta a como lo propone la Ley. Es poder político, dependiente del Presidente, y tema resuelto. Y para contrarrestar este inmenso poder, ya están la ley, el Juez, el Jurado, y el abogado defensor del acusado.

Hasta aquí el apunte de Derecho comparado. Sólo añadiré que ningún país verdaderamente democrático contempla la elección del Fiscal General por el Parlamento, que a veces se ha propuesto en España ${ }^{16}$. Es una experiencia de la época comunista (era el sistema de los países bajo la órbita de la Unión Soviética), que nadie avala hoy para no ser erróneamente identificado, porque el Parlamento era en esos países, y es en los pocos comunistas que queden todavía, un monopolio político del único partido legal en el país ${ }^{17}$.

Pues bien, ésa otra razón a la que me refería antes de entrar en el Derecho comparado, que debe resolver esta cuestión de una vez, es de naturaleza dogmática, mucho más profunda, y tiene que ver con la reforma global de nuestro proceso penal que, con dos Anteproyectos, que nunca llegaron a buen puerto, en los últimos diez años, ambos publicados, pretendían orientar nuestro sistema de enjuiciamiento criminal hacia el sistema adversarial anglosajón: El Anteproyecto del Gobierno del PSOE de $2011^{18}$, frustrado por las elecciones generales; y la propuesta del Gobierno del PP de $2013^{19}$, truncada por oposición de los operadores jurídicos más relevantes que tenían que practicarla, y eso que disponía de mayoría absoluta y tiempo suficiente para aprobarla.

En este sentido, en el sistema adversarial, como acabamos de ver qué sucede en los Estados Unidos de Norteamérica, el Fiscal es un órgano político, depende

16 Principalmente por la Unión Progresista de Fiscales, aunque en la despolitización están todas las asociaciones de fiscales de acuerdo, v. http://www.europapress.es/nacional/noticia-asociaciones-fiscales-piden-gobierno-no-nombre-fiscal-general-estado-20170524184421.html.

17 Véase sobre los antiguos países comunistas, Martínez Dalmau, R., Aspectos constitucionales del Ministerio Fiscal, cit., págs. 89 y ss.

18 El Gobierno socialista español aprobó en Consejo de Ministros el día 22 de julio de 2011 el proyecto de una nueva Ley de Enjuiciamiento Criminal basada en el sistema acusatorio (adversarial), cuyo anteproyecto fue elaborado por una comisión de expertos con muchísima más presencia de prácticos que de teóricos, lo que en un cambio de modelo resulta bastante sorprendente. Un acto por cierto puramente testimonial porque el texto de referencia ni siquiera pudo superar el trámite parlamentario inicial al haberse disuelto las cámaras el día 27 de septiembre de 2011, por adelanto de las elecciones al día 20 de noviembre de 2011. La esperanza previa a las elecciones de retomar la tarea después, se esfumó completamente al perderlas. Se puede consultar en Ministerio de Justicia, Anteproyectos de ley para un nuevo proceso penal, Secretaría General Técnica - Ministerio de Justicia, Madrid 2011, págs. 19 y ss.

19 El texto se puede consultar en el momento de escribir estas líneas en la página web del Ministerio: http://www.mjusticia.gob.es/cs/Satellite/es/1215198252237/ALegislativa_P/1288775964668/Detalle.html 
del Gobierno, el Fiscal General de los Estados Unidos es el Ministro de Justicia, y su actuación se visualiza en ese gran país como una actuación propia del Gobierno (la Administración) en contra del acusado. No solamente no hay ningún problema en que el Fiscal sea un órgano político, sino que, además, no puede ser más que político.

Por ello, cualquier reforma global, o más allá, una nueva Ley de Enjuiciamiento Criminal que quiera tomar como modelo el sistema adversarial, y en concreto el proceso penal federal de los Estados Unidos de Norteamérica, no puede pensar en un Fiscal distinto, ni disfrazándolo con falsas etiquetas (afirmando su independencia o su imparcialidad), ni confundiendo con su configuración orgánica (diciendo que está integrado con autonomía funcional en el Poder Judicial).

Añádase que si el Ministerio Fiscal es quien ejecuta la Política Criminal del Gobierno (con la salvedad indicada supra), debe ser, además de un órgano jurídico, un órgano político, por tanto, debe incardinarse en el Poder Ejecutivo. Por eso la inmensa mayoría de los países lo consideran de esta naturaleza y lo regulan en coherencia con ello. Pero, obsérvese, que en los cuatro países que hemos visto aquí, cada uno lo establece de manera distinta.

Que se quiera dotar de una mayor legitimidad democrática haciendo partícipe al Parlamento (democráticamente elegido) en el nombramiento de Fiscal General, como sucede en España (en donde el control no es vinculante), para nada cambia su naturaleza, y, además, el control democrático, si no vincula al órgano proponente, nunca es determinante de su naturaleza.

Por ello y en mi modesta opinión, si un día el sistema de enjuiciamiento criminal español es adversarial, el Fiscal en España debería ser un órgano constitucional político, dependiente del Ministerio de Justicia. Así no habrá engaños ni discusión posible. Así todo acusado esperará lo que tiene que esperar del Poder Político, a saber, que el Gobierno, defendiendo a la Sociedad con uno de sus poderosos brazos, el Ministerio Fiscal, le exija responsabilidad por su crimen. Por tanto, si ya era para nosotros un órgano político, en el futuro debe serlo todavía más.

\section{EL MINISTERIO FISCAL EN EL PROCESO PENAL, ¿FUNCIONALMENTE INSTRUCTOR Y PARTE ACUSADORA, O SÓLO PARTE ACUSADORA?}

La segunda cuestión importante que nos ocupa es si debe instruir las causas penales el Ministerio Fiscal o, al contrario, debe mantenerse en España el actual sistema de Juez Instructor y Fiscal parte actora. Este tema es muy sensible entre nosotros. Ha llegado hace ya tiempo a España ${ }^{20}$, adquiriendo enseguida tintes

20 Véase Fairén Guillen, V., «La reorganización del Ministerio Fiscal español», en Temas del Ordenamiento Procesal, Tecnos, Madrid 1969, t. I, págs. 516 y 517. Hemos tratado estas cuestiones también en GómEZ 
polémicos, sin duda motivados por exceder de la vertiente estrictamente jurídica esta delicada cuestión, y sigue vivo como tema de discusión de primer orden ${ }^{21}$.

Una aclaración previa. Un sector doctrinal distingue en la fase de averiguación del crimen entre investigación e instrucción, para sostener que la investigación debe atribuirse al Ministerio Fiscal, mientras que no hay inconveniente en que la instrucción siga siendo judicial, al menos para las decisiones sobre actos que puedan afectar a los derechos fundamentales de los imputados. Me parece una distinción artificial, o al menos poco fructífera y nada práctica, por las siguientes razones:

Primero, porque quien investiga realmente es la Policía, no la Fiscalía ni mucho menos el Juez Instructor, y es esta institución la que hay que regular y controlar;

Segundo, porque investigar e instruir es formalmente lo mismo. Cuando el fiscal o el juez ordenan la declaración de un testigo de los hechos, está al mismo tiempo investigando qué ha pasado y construyendo un expediente que le servirá para determinar si sigue adelante (acusación) o si termina antes de tiempo (sobreseimiento). Lo mismo pasa si ordena un informe pericial, una entrada y registro domiciliario o una interceptación de e-mails. Que existan en la fase preparatoria del proceso penal (sumario, diligencias previas o urgentes), actos que no son de investigación, como las citaciones, no empece a que todo lo actuado dé forma a una investigación, que en su consideración global es una investigación instruída, construída u ordenada en suma.

Pues bien, el problema de la discusión anunciada es que está politizada. La politización surge cuando se defiende la instrucción a cargo del Ministerio Fiscal, por entender quien así opina que el modelo de instrucción criminal judicial no es conforme con la Constitución española. Sobre esta cuestión, importante, volveremos luego. Pero también cuando se tilda como partidario de una determinada concepción política a quien defiende una posición u otra, siendo así que la Justicia es una cuestión de Estado y no de partido. Nuestras palabras, muy al contrario, pretenden fundar rigurosamente una postura jurídica, fuera de todo contexto no jurídico, con la única meta de contribuir a una Justicia mejor y más eficaz, pero partiendo coherentemente de la consideración política de la Fiscalía que acabábamos de defender en el punto anterior, y de ahí su estrecha relación.

En este sentido, en España instruye un Juez Instructor todas las causas penales (arts. 87.1, a) de la Ley Orgánica del Poder Judicial —abreviada LOPJ—, de 1985, y 14-2 ${ }^{\circ}$ de la Ley de Enjuiciamiento Criminal —abreviada LECRIM—, de

Colomer, J.L., «El Fiscal instructor», Revista Justicia 1996, núm. 2, págs. 259 y ss.; y del mismo autor, «La instrucción del proceso penal por el Ministerio Fiscal: Aspectos estructurales a la luz del Derecho Comparado», en Gómez Colomer, J.L. / GonzÁlez Cussac, J.L. (coordinadores), La Reforma de la Justicia Penal. Estudios en homenaje al Prof. Dr. Dr.h.c. Klaus Tiedemann, Universitat Jaume I, Castellón 1997, págs. 459 y ss.

21 Véase el excelente artículo de Dolz Lago, M.J., «Nuevas perspectivas sobre sistema acusatorio e instrucción penal: El papel del Ministerio Público en España», La Ley núm. 100, págs. 22 y ss. 
1882), salvo que en el proceso penal abreviado, en el proceso para el enjuiciamiento de determinados delitos y en el juicio por delitos leves (en éstos dos últimos siempre que fuera posible, dada la supletoriedad prevista en los arts. 795.4 y concordantes LECRIM, lo que es discutible), el Fiscal tenga conocimiento de un hecho aparentemente delictivo, bien directamente, bien por serle presentada una denuncia o atestado, en cuyo caso puede instruir el Ministerio Fiscal ${ }^{22}$, función que termina cuando se haya incoado un procedimiento judicial por los mismos hechos, o cuando haya concluido las necesarias investigaciones para solicitar del Juez de Instrucción la incoación del procedimiento judicial correspondiente (arts. 773.2 LECRIM) ${ }^{23}$. Claro es que el Ministerio Fiscal, con anterioridad a esta reforma, siempre ha podido y debido realizar unas primeras investigaciones de los

22 El Anteproyecto de la Ley Orgánica, que más tarde sería la núm. 7/1988, de 28 de diciembre, creadora del proceso penal abreviado, previó inicialmente sin ambages que la instrucción fuera a cargo del Ministerio Fiscal en su integridad, pero los arts. 781 y 781 bis que se reformaban e introducían en la LECRIM, fueron suprimidos en los inicios de las discusiones parlamentarias, frente a las críticas emitidas por el Consejo General del Poder Judicial, v. su Informe en el Boletín de Información del Consejo General del Poder Judicial de octubre de 1988, págs. 17 y 18.

23 Véanse Ortells Ramos, M., «Problemas de contenido y delimitación de las fases del procedimiento abreviado (diligencias previas, fase intermedia, juicio oral)», en Cuadernos de Derecho Judicial. El procedimiento abreviado, Consejo General del Poder Judicial, Madrid 1992, págs. 111 y ss.; del mismo autor, «El nuevo procedimiento penal abreviado: Aspectos fundamentales», Revista Justicia 1989, núm. III, págs. 545 y ss. Complementariamente pueden consultarse: Armenta Deu, T., Lecciones de Derecho Procesal Penal ( $2^{\mathrm{a}}$ ed.), Marcial Pons, Madrid 2004, págs. 98 y ss. Moreno Catena, V. / Cortes Dominguez, V., Derecho Procesal

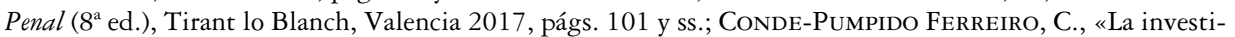
gación por el Ministerio Fiscal y la utilización de la oportunidad reglada en el proceso penal», en El Poder Judicial en Europa. Conferencia en Madrid de los Presidentes y Fiscales Generales de los Tribunales Supremos de los Estados miembros de las Comunidades Europeas, Consejo General del Poder Judicial, Madrid 1989, t. II, págs. 113 y ss.; De Llera SuÁrez-BÁrcena, E., «El modelo de investigación penal de la CE de 1978: Los papeles asignados al Juez, al Fiscal y a la Policía Judicial», Revista del Ministerio Fiscal 1998, núm. 5, págs. 93 y ss.; Idem, El modelo constitucional de investigación penal, Tirant lo Blanch, Valencia 2001, págs. 119 y ss.; EscusOl BARRA, E., El proceso penal por delitos: Estudio sistemático del procedimiento penal abreviado (Ley Orgánica 7/1988, de 28 de diciembre) (2 $2^{\mathrm{a}}$ ed.), Colex, págs. 99 y ss.; Fernández Bermejo, M., «El Fiscal en el proceso abreviado de la Ley Orgánica 7/1988», en Cuadernos de Derecho Judicial. El procedimiento abreviado, cit., págs. 237 y ss.; FLORES Prada, I., El Ministerio Fiscal en España, Tirant lo Blanch, Valencia 1999, págs. 489 y ss.; IzaGuirre GueRricagoitia, J., La investigación preliminar del Ministerio Fiscal. La intervención de las partes en la misma, Aranzadi, Pamplona 2001, págs. 149 y ss.; López López, A.M., «Las diligencias del Fiscal investigador», Revista Actualidad Penal 1993, t. I, núm. 15, de 12-18 de abril; LorCa Navarrete, A.M., «La instrucción preliminar en el proceso penal: La actividad de la Policía Judicial», Revista La Ley 1984, t. III, págs. 970 y ss.; MARtínez Dalmau, R., Aspectos constitucionales del Ministerio Fiscal, cit., págs. 199 y ss.; Montull Lavilla, E., «Hacia la independencia, jurídicamente garantizada, del Ministerio Fiscal en el cumplimiento de la misión y el ejercicio de las funciones que la Constitución española le asigna», Revista Española de Derecho Militar 2006, núm. 87, págs.. 89 y ss.; NARváez Rodríguez, A., «La investigación penal por el Ministerio Fiscal: Una apuesta de futuro», Tribunales de Justicia - Revista Española de Derecho Procesal 2000, núm. 10, págs. 1067 y ss.; Toro PeÑA, J.A., «El Ministerio Fiscal o el juez de instrucción, como órgano encargado de la fase de instrucción en el proceso penal», Revista La Ley 2012, núm. 7885; SANCHIS Crespo, C., El Ministerio Fiscal y su actuación en el proceso penal abreviado. Especial referencia al procedimiento preliminar fiscal, Comares, Granada 1995, págs. 45 y ss.; VALDÉs-Solís IGLESIAS, F., «Garantías actuales de los representantes del Ministerio Fiscal y reformas necesarias para una mayor independencia en garantía de los derechos de los ciudadanos», Revista La Ley 2012, núm. 7851; Zarzalejos Nieto, J., en De La Oliva Santos / Vegas Torres / Zarzalejos Nieto / González García / Aragoneses Martínez, Nuevos Tribunales y nuevo proceso penal, La Ley, Madrid 
hechos delictivos producidos y denunciados, como es lógico, y así fue recogido expresamente en el art. 5, II EOMF, si bien de carácter tímido ${ }^{24}$. Un caso particular de instrucción a cargo del Ministerio Fiscal lo constituye el proceso penal especial de menores ${ }^{25}$, de correcto funcionamiento en la práctica, pero poco significativo al nivel que estamos considerando esta cuestión ${ }^{26}$.

Como precedentes o intentos de introducir en España más generalmente la instrucción a cargo del Fiscal hay que citar, sin ulteriores comentarios, el Proyecto de Estatuto Orgánico del Ministerio Fiscal de 1980 (art. 3.4), que no salió adelante, y destacar el apoyo oficial dado en la Memoria de la Fiscalía General del Estado de $1987^{27}$, la primera que toca el tema repitiéndose desde entonces en todas ellas. Jurisprudencialmente se sentaron ciertas bases en la S TC 145/1988, de 12 de julio, que declaró parcialmente inconstitucional la LO 10/1980, y que fue el origen del proceso penal abreviado ${ }^{28}$.

1989, págs. 159 y ss.; y Vives Antón, T.S., «Comentarios a la Ley de Medidas Urgentes de Reforma Procesal», vol. II La reforma del proceso penal, Tirant lo Blanch, Valencia 1992, págs. 167 y ss.

24 Véase Marchena Gómez, M., El Ministerio Fiscal: Su pasado y su futuro, cit., pág. 179.

25 Fue el art. 15.1-2 ${ }^{\circ}$ de la Ley de Tribunales Tutelares de Menores de 1948, reformado por la Ley Orgánica 4/1992, de 5 de junio, declarado constitucional por la S TC 60/1995, de 17 de marzo, el que atribuyó la competencia al Fiscal, norma precedente actualmente vigente. Véase sobre el tema Dolz LAGO, M.J., «El Fiscal y la reforma de menores. Balance de experiencias tras la Ley Orgánica 4/1992», Revista Vasca de Derecho Procesal y Arbitraje 1995, cuaderno 3, págs. 480 a 483, y 488 y 489.

26 Hoy son los arts. 6 y 16.1 de la Ley Orgánica 5/2000, de 12 de enero, reguladora de la Responsabilidad Penal de los Menores, varias veces reformada. V. Dolz LAGo, M.J., La nueva responsabilidad penal del menor (Comentarios a la Ley Orgánica 5/2000, de 12 de enero), Revista General del Derecho, Valencia 2000, págs. 144 y ss.; y, del mismo autor, Comentarios a la Legislación penal de menores. Incorpora las últimas reformas legales de la LO 8/2006, Tirant lo Blanch, Valencia 2007, págs. 72 y ss. Es importante igualmente consultar la Circular 1/2000, de 18 de diciembre, sobre esta Ley Orgánica, y en concreto su apartado VI.

27 Véase la Memoria de la Fiscalía General del Estado, Madrid 1988, pág. 15. Debo añadir que, políticamente, hace tiempo que el tema de decidir quién va a instruir en España el proceso penal se considera una de las cuestiones más importantes, y polémicas que necesariamente deberá abordar la futura Ley de Enjuiciamiento Criminal, tal y como se reconoció en el Pacto de Estado para la Reforma de la Justicia, de 28 de mayo de 2001, firmado entre el Gobierno del Partido Popular y el principal partido de la oposición, el Partido Socialista Obrero Español. Su apartado 9, dedicado al Ministerio Fiscal, decía textualmente que «... en lo funcional, habrá de estarse principalmente a lo que disponga una nueva Ley de Enjuiciamiento Criminal»; y el apartado 17, dedicado a la Ley de Enjuiciamiento Criminal, disponía en su último párrafo que «la tramitación de la reforma de conjunto afrontará y resolverá para el futuro el debate sobre la investigación previa al proceso penal de los procedimientos por el Fiscal o por el Juez...» Se observa que el Pacto no optó por ningún modelo, más bien fue cauto, aplazando simplemente la discusión. Vide GómEz COLOMER, J.L., «El Fiscal instructor», cit., págs. 259 y ss.; y del mismo autor, «La instrucción del proceso penal por el Ministerio Fiscal: Aspectos estructurales a la luz del Derecho Comparado», cit., págs. 459 y ss. El Partido del Gobierno actual (2017) ha propuesto un Plan Anual Normativo para 2018, en el que contempla elaborar 287 normas, de las cuales 9 serían leyes orgánicas, 38 leyes ordinarias y 240 reales decretos, además de transponer 52 directivas comunitarias. Entre las leyes está una nueva Ley Orgánica de Enjuiciamiento Criminal, que supere el modelo del siglo XIX y nos iguale al resto de países europeos y americanos, atribuyendo la dirección de la investigación al Ministerio Fiscal (pág. 16). Este extenso documento de 130 páginas se puede consultar on line en: http://www. lamoncloa.gob.es/consejodeministros/referencias/documents/2017/refc20171207e_2.pdf.

28 Véase también la Circular 1/1989, de 8 de marzo, de la Fiscalía General del Estado, sobre el procedimiento abreviado introducido por la Ley Orgánica 7/1988, de 28 de diciembre, publicada en la Memoria de la Fiscalía General del Estado de 1988, Madrid 1989, págs. 395 y ss., esp. págs. 430 y 431. Una 
Mención especial merece la Ley del Jurado, porque en el primer texto que elaboró el Ministerio de Justicia se quería introducir también la instrucción a cargo del Fiscal, que luego fue transformado en el Proyecto remitido a Las Cortes por una constitución del Fiscal al lado del Juez Instructor durante la investigación, para quedar finalmente en el texto aprobado (Ley Orgánica 5/1995, de 22 de mayo, reformada por las Leyes Orgánicas 8/1995 y 10/1995), en una mayor presencia del Fiscal en la fase de investigación (nuevos arts. 306, III y 781, V LECRIM, reformados por dicha Ley), aunque la disposición final cuarta autorizó un estudio a fondo de este tema en la proyectada futura reforma del proceso penal español ${ }^{29}$.

Veamos ahora, como hicimos en el punto primero de este artículo, qué sucede en nuestro entorno jurídico.

a) Lo que nos enseña el Derecho comparado: Dos grandes líneas se contemplan inmediatamente ${ }^{30}$ :

$\left.1^{a}\right)$ En Europa continental, un observador atento de la realidad jurídica deduce inmediatamente que desde $1974^{31}$, fecha en que en Alemania se da un vuelco legal a favor del sistema anglosajón de instrucción a cargo de persona distinta al Juez (Policía y Ministerio Fiscal) ${ }^{32}$, sin duda la más importante de todas las propuestas antedichas, abandonando la tradicional competencia del Juez Instructor para esta fase inicial del proceso penal, los demás países las han ido contemplando todas ellas o una buena parte de las mismas. Consideraremos pues Alemania, Italia y Francia.

$\left.2^{a}\right)$ En el sistema adversarial, desde prácticamente su origen en el proceso penal federal de los Estados Unidos de Norteamérica, el crimen es investigado por el Ministerio Fiscal y, de facto, por la Policía.

\section{A) Alemania}

En Alemania, la Strafprozeßordnung de 1877 —abreviada StPO-, reformada según se ha indicado en 1974 en este importante tema, recoge la instrucción a

explicación detallada en Gómez COLOMER, J.L., «El debate acerca del quién de la investigación a la luz de la experiencia y el modelo procesal alemán», Revista Estudios Jurídicos. Ministerio Fiscal. El Ministerio Fiscal en el Derecho Comparado - El Consejo Fiscal, 2001, núm. VI, págs. 97 y ss.

29 Véanse Gómez Colomer, J.L., El proceso penal especial ante el Tribunal del Jurado, Civitas, Madrid 1996, págs. 145 a 147; y Salom Escrivá, J.S., en Montero Aroca, J. / Gómez Colomer, J.L. (Coordinadores), Comentarios a la Ley del Jurado, Aranzadi, Pamplona 1999, págs. 1000 y 1001.

30 Para no reiterar, me remito a la bibliografía citada en la nota 3 de este escrito.

31 Mediante la Erstes Gesetz zur Reform des Strafverfabrensrechts, abreviada 1. StVRG («Primera Ley de Reforma del Derecho Procesal Penal»), de 9 de diciembre de 1974, conocida doctrinalmente como la «Gran Reforma del Proceso Penal», v. sobre sus aspectos más importantes KERN / RoxIN, Strafverfahrensrecht $\left(14^{\mathrm{a}}\right.$ ed.), C.H. Beck, München 1976, págs. 353 y 354; y Roxin, C., Strafverfabrensrecht (15ª ed.), C.H. Beck, München 1979, págs. 373 a 375.

32 Véase una explicación detallada de esta reforma alemana en Pedraz Penalva, E., «La reforma procesal penal de la R. F. de Alemania de 1975», Revista de Derecho Procesal Iberoamericana 1976, págs. 647 y ss. 
cargo del Fiscal en sus $\S \S 160$ a $163^{33}$. El $\S 160$, ap. (1) es la clave ${ }^{34}$. La Fiscalía ordena a la Policía que investigue los hechos aparentemente delictivos ( $\$ 163$ StPO), conforme a sus técnicas propias, siendo en la práctica la Policía la verdadera instructora de las causas criminales ${ }^{35}$.

El Juez sólo puede intervenir para adoptar resoluciones que impliquen restricciones de derechos fundamentales, principalmente de la libertad ( $\mathrm{v}$. por ejemplo, entre otros muchos, los $\S$ 65, 114, 126a, y 161a StPO) $)^{36}$; el Ministerio Público es, ante todo, el dueño del proceso penal, porque es el único acusador en el mismo, gozando del monopolio de la acción penal ( $\$ 243$, ap. 3 StPO).

De ello se deduce ${ }^{37}$ :

a) Que no es parte (en sentido material) en el proceso penal, pues debe averiguar no sólo las circunstancias y los hechos que hablen en contra del inculpado, sino también los que se pronuncien a su favor ( $\$ 160$, ap. 2 StPO).

b) Que, en caso de existencia de un acto punible, está obligado, en principio, a presentar la acusación ( $§ 152$, ap. 2 StPO).

c) Se discute si el Ministerio Fiscal, no considerando punible el hecho cometido por el inculpado, ya por motivos fácticos, ya por motivos jurídicos, puede ser obligado por su superior a acusar, solicitar la orden penal u otras medidas ulteriores, porque el $\S 144 \mathrm{GVG}$ considera a este funcionario un sustituto del superior máximo, del primer funcionario de la Fiscalía. En general, se opina que ello no es correcto, porque obligar a una actuación en contra del convencimiento personal de quien debe realizarla, iría contra la Verdad y la Justicia, sustituyéndose en la práctica al Fiscal o encomendado la causa a otro. El § 145, ap. 1 GVG, evitaría la insolubilidad del problema, pues ese primer funcionario siempre podría aceptar practicar él mismo la actuación puesta en entredicho.

d) Es cuestión discutida asímismo si existe obligación de acusar, cuando el Ministerio Fiscal considera también no punible determinado comportamiento, en contra de la Jurisprudencia, con base en supuestos análogos con relación a los Tribunales entre sí, previsto en el $\S 121$, ap. $2 \mathrm{GVG}^{38}$, pero, obsérvese, claramente en contra, ese basamento, de la independencia del Fiscal respecto a los Tribunales, proclamada en el $\S 150$ GVG. La Verdad y Justicia deben prevalecer, por tanto, también en esta cuestión. Sin embargo, el Tribunal Supremo Federal

33 Una exposición doctrinal y la traducción de la legislación alemana citada en Gómez COLOMER, J.L., El proceso penal alemán. cit., págs. 281 y correspondientes.

34 Véase Gómez Colomer, J.L., El proceso penal alemán..., cit., pág. 337.

35 Así lo confirma expresamente Peters, K., Strafprozeß, cit., págs. 182 y 183.

36 Un resumen detallado de la posición del Juez Investigador alemán instruyendo el Fiscal, en GómEz Colomer, J.L., El proceso penal alemán..., cit., págs. 73 a 75.

37 Roxin, Strafverabrensrecht (29a ed.), cit., págs. 56 y 57.

38 Antes de la derogación por la Ley de 17 de febrero de 1990 del art. 136 GVG, se basaba también en este precepto. 
alemán o BGH afirma al respecto, en constante Jurisprudencia, que el Fiscal está obligado en este caso a acusar ${ }^{39}$.

Finalmente, el Fiscal desarrolla en el proceso penal las siguientes actividades ${ }^{40}$ :

a) Tramita las solicitudes penales que se le presenten, e investiga las denuncias que se pongan en su conocimiento ( $\$ 158 \mathrm{StPO})$;

b) Instruye el procedimiento preliminar: Es el órgano competente para realizar las actuaciones propias deł procedimiento de averiguación, preparatorio o preliminar (nuestro sumario o diligencias previas), completamente, desde el punto de vista legal, en sus manos ${ }^{41}$; es, por tanto, el guía, director y señor del mismo ( $§ 160$ y ss. StPO).

c) Acusa, es decir, tomar la decisión sobre si ejerce la acción pública $(\S \S 152$ y $170 \mathrm{StPO}$ ). Sobre ello téngase en cuenta la vigencia en Alemania del principio de oportunidad, por el que el Ministerio Fiscal, como excepción al principio de legalidad, por razones de prevención general y especial, y con la aprobación del Tribunal, puede prescindir de la persecución de determinados delitos leves, o de aquéllos que por otras razones no se considere conveniente perseguir, al amparo de los $\S \S 153$ y ss. StPO ${ }^{42}$.

d) Debe acusar en la vista principal ( $\$ 226$ y 243 , ap. 3 StPO, y, en principio, es el único legitimado para ello ${ }^{43}$, como queda afirmado.

\section{B) Italia}

Algo parecido se podría decir de Italia, cuyo Código de Procedimiento Penal de $1988^{44}$, que ha derogado el de 1930 (el Código ROCCO) ${ }^{45}$, prevé el monopolio de la acción pública por parte del Ministerio Fiscal (arts. 50, 405 y 416 CPP,

39 Véase Peters, Strafprozeß, cit., pág. 167.

40 Baumann, Grundbegriffe und Verfahrensprinzipien des Strafprozeßrechts, Kohlhammer, Stuttgart 1979, págs. 111 a 117; Roxin, Strafverfabrensrecht (29a ed.), cit., págs. 54 y 55; y, extensamente, PETERs, Strafprozeß, cit., págs. 166 y ss.

41 Gráficamente denominan Peters, Strafprozeß, cit., págs. 166 y 167; Tiedemann, en Roxin / ArzT / Tiedemann, Einführung in das Strafrecht und Strafprozeßrecht (3 ${ }^{\mathrm{a}}$ ed.), C.F. Müller, Heidelberg 1994, pág. 161; y EsEr, Einfübrung in das Strafprozeßrecht, C.H. Beck, München 1983, pág. 21, a la Fiscalía «señora del procedimiento de averiguación».

42 Véase Gomez Colomer, J.L., El proceso penal alemán... cit., págs. 47 y 48.

43 Se dice por ello que el Ministerio Fiscal tiene el monopolio de la acción, v.v.gr., EsER, op. y loc. cit.

44 Véase la traducción de Villagómez, M., El nuevo proceso penal italiano, cit., págs. 41 y ss.

45 Véase sobre la historia procesal penal italiana, Chiavario, M., Procedura Penal. Un Codice tra «storia» e cronaca, Giappichelli, Torino 1994, págs. 13 a 32. Esta Ley preveía la competencia exclusiva del Juez para la formación de las causas penales, denominada instrucción formal (art. 303), con la excepción de la llamada instrucción sumaria, a cargo del Ministerio Fiscal según el art. 389 (o del Pretor para los delitos de su competencia). También Rolla, G., «El Ministerio Público en Italia. Disciplina constitucional», en Revista Pensamiento Constitucional, Año VII, núm. 7, págs. 259 y ss., que se puede consultar en: http://revistas.pucp. edu.pe/index.php/pensamientoconstitucional/article/viewFile/3264/3101. 
con fundamento en el art. 112 de la Constitución de 1948) ${ }^{46}$, la instrucción del proceso penal a su cargo (arts. 327 y $358 \mathrm{CPP}$ ), las medidas alternativas a la persecución penal (arts. 444 y ss. CPP), así como una intervención principal en la ejecución de resoluciones judiciales (arts. 655 y $656 \mathrm{CPP}$ ), sin perjuicio de la intervención del Juez de las Investigaciones Preliminares (v. arts. 279, 283, 294, etc., por ejemplo, del CPP), o del llamado Tribunal de la Libertad, instaurado en 1984, en la fase de investigación (v. art. 309 CPP), o del Magistrado de Vigilancia en la ejecución de la pena privativa de libertad (arts. 677 y ss. CPP $)^{47}$.

No se distingue entre instrucción formal o sumaria, a cargo del «Pubblico Ministero», disponiendo textualmente su art. 327.1 que «Il pubblico ministero dirige le indagini e dispone direttamente della polizia giudiziaria» ${ }^{48}$, concretándose a continuación esta facultad en los arts. 328 y ss. ${ }^{49}$

\section{C) Francia}

Por lo que hace referencia a Francia, el papel del Juez de Instrucción en el proceso penal del país vecino ${ }^{50}$ es uno de los más importantes de la Europa actual, hasta tal punto que se le ha denominado "l'bomme le plus puissant de France», hoy ciertamente venido a menos por los derechos de la defensa ${ }^{51}$. El Juez de Instrucción francés ha pasado de oficial superior de la Policía Judicial, de acuerdo con el

46 Véanse, en cuanto a bibliografía de la época, Condero, F., Procedura Penale ( $5^{\mathrm{a}}$ ed.), Giuffrè, Milano 1979, págs. 432 a 439; Foschini, G., Sistema del Diritto Processuale Penale (2a ed.), Giuffrè, Milano 1965, tomo II, págs. 128 a 130 y 166 a 170; Manzini, V., Tratatto di Diritto Processuale Penale italiano (6a ed., puesta al día por Conso y Pisapia), UTET, Torino 1972, vol. IV, págs. 181 y 293; y PISAPIA, G.D., Compendio di Procedura Penale (2 ${ }^{\mathrm{a}}$ ed.), CEDAM, Padova 1979, págs. 76, 77 y 172.

47 Vide Chiavario, M., La riforma del processo penale. Appunti sul nuovo codice (2a ed.), UTET, Torino 1990 , págs. 78 y ss.

48 Véanse, citando expresamente las ediciones de la época, Chiavario, M., La riforma del processo penale..., cit., págs. 83 a 89; Carulli / Massa / Esposito / Palumbo, Lineamenti del nuovo processo penale, Jovene, Napoli 1993, págs. 26 y ss.; Dalia / Ferraioli, Corso de Diritto Processuale Penale, Cedam, Padova 1992, págs. 341 y ss.; Fortuna / Dragone / Fassone / Giustozzi / Pignatelli, Manuale Pratico del Nuovo Processo Penale (3 ${ }^{\mathrm{a}}$ ed.), Cedam, Padova 1993, págs. 95 y ss., y 153 y ss.; NAPPI, A., Guida al nuovo Codice di Procedura Penale, Giuffrè, Milano 1992, págs. 30 y ss.; PISAni / Molari / Perchinunno / Corso, Appunti di Procedura Penale, Monduzzi, Bologna 1992, págs. 57 y ss.; y Cordero, F., Procedura Penale (2a ed.), Giuffrè, Milano 1993, págs. 133 y ss. Una resumida visión constitucional del tema puede verse en ConTi, G., La Giurisprudenza della Corte Costituzionale sul processo penale, dall'entrata in vigore del nuovo Codice di Procedura Penale al 31 ottobre 1991, Corte Costituzionale 1992, págs. 425 y ss. Vide asímismo Mateos Rodriguez-Arias, A., «El Ministerio Público en el nuevo Código de Procedimiento Penal italiano. Su función investigadora y sus relaciones con la Policía Judicial», Revista Poder Judicial 1994, núm. 34, págs. 253 y ss.

49 Biavati, P. / Guarneri, C. / Orlandi, R. / Zanon, N., La giustizia civile e penale in Italia, cit., págs. 229 y ss.

50 Véanse sobre la historia del proceso penal francés, Laingui, A. / Lebigre, A., Histoire du Droit Pénal, II (La procédure criminelle), Cujas, París, sin fecha (probablemente 1979).

51 Véase Larguier, J., La procédure pénale ( $8^{\mathrm{a}}$ ed.), Presses Universitaires de France, que sais-je, París 1994, pág. 20. 
Code d'instruction criminelle de 1808 , a verdadero órgano jurisdiccional de instrucción con la reforma operada por la Ley de 17 de julio de 1856, de manera tal que hoy, no siendo ya un «agent d'information» subordinado al Procurador de la República, está encargado de recopilar las pruebas del hecho criminal y averiguar la participación del inculpado en el mismo, es decir, de realizar actos de información, y además actúa con verdadera jurisdicción al decidir si dicho inculpado debe ser enviado a juicio o no ${ }^{52}$.

Al Juez de Instrucción francés le corresponde, pues, la función de instruir en primer lugar (la obligación de perseguir está atribuida al «Procureur de la République»), de acuerdo con el art. 81 y concordantes del Code de Procédure Pénale de $1958^{53}$. El Ministerio Público, debe ejercer la acción pública ${ }^{54}$. Tiene a su cargo, además del poder de persecución, lo que en Francia se llama la «enquête préliminaire» ${ }^{55}$, es decir, las primeras averiguaciones, que realiza con la ayuda de la Policía Judicial ${ }^{56}$.

Depende del Ministerio de Justicia, quien le imparte instrucciones para desarrollar la política criminal del Gobierno (art. 30 Código Procesal Penal).

Pero hay actualmente una gran discusión sobre el Juez de Instrucción en Francia, proponiéndose la supresión de la instrucción judicial, sobre todo tras casos muy complejos surgidos en el país vecino ${ }^{57}$.

\section{D) Estados Unidos}

Por lo que afecta a los Estados Unidos de Norteamérica, la influencia del Derecho inglés es evidente, pero con instituciones propias que lo hacen diferente ${ }^{58}$. En

52 Véanse Stefani, G. / Levasseur, G. / Bouloc, B., Procédure Pénale (23a ed.), Dalloz, París 2012 , págs. 147 a 155; Pradel, J., Procédure Pénale (16 ed.), Cujas, París 2011, págs. 121 y ss.; GuinCHard, S. I Buisson, J., Procédure Pénale (7ª ed.), LexisNexis, Paris 2011, págs. 271 y ss.; y Kernaleguen, F., Institutions judiciaires, Litec, París 1994, págs. 138 a 140.

53 Hemos manejado la edición de PRADEL Y CASORLA, Dalloz, París 1996. Véase Rozìs, S., «Le Juge d'Instruction», en Strafrecht, Unternehmensrecht, Anwaltsrecht. Festschrift für Gerd Pfeiffer zum Abschied aus dem Amt als Präsident des Bundesgerichtshofes (coordinado por Von Gamm, Raisch Y Tiedemann), C. Heymanns, Köln-Berlin-Bonn-München 1988, págs. 175 y ss., esp. pág. 177.

54 Véanse Stefani, G. / Levasseur, G. / Bouloc, B., Procédure Pénale, cit., págs. 163 y ss.; y Pradel, J., Procédure Pénale, cit., págs. 131 y ss.

55 Véase Larguier, J., La procédure pénale, cit., págs. 59 a 64.

56 Véanse sobre sus competencias, fundamentalmente de conocimiento de recursos contra resoluciones del Juez de Instrucción, y su composición, Stefani, G. / Levasseur, G. /Bouloc, B., Procédure Pénale, op. et loc. cit.

57 Véase el Rapport du Comité de Réflexion sur la Justice pénale (Informe LÉGER) de 1 de septiembre de de 2009, en: http://www.justice.gouv.fr/art_pix/sg_rapport_leger2_20090901.pdf.

58 No se olvide que es un Estado Federal, regido por una Constitución, de 1787, a la que se han añadido las X Enmiendas (Bill of Rights) de 1791, con disposiciones procesales penales importantes que recogen todo un catálogo de derechos y libertades fundamentales, más el Derecho Penal y Procesal Penal federal (formado por numerosas leyes o Federal Statutes, una de las cuales, el llamado United States Code, establece lo esencial de los delitos federales y del proceso penal federal, complementado por las Federal Rules of Criminal Procedures for the U.S. District Courts, las Federal Rules of Appellate Procedure y las Federal Rules of Evidence), y el propio de cada Estado (State Statutes). Véanse Israel, J.H. / Kamisar, Y. / Lafave, W.R. / KInG, N.J., Criminal Procedure and the Constitution. 
USA la acusación del proceso penal está a cargo de una figura pública o funcionario, dado que acusa en nombre del Estado federado, o de los Estados Unidos. Ese funcionario es un representante (Assistant) del U.S. Attorney General (el Fiscal General Federal y Ministro de Justicia), que tiene encomendado, dentro de los límites de su competencia territorial, es decir, dentro de su distrito, en los procesos penales federales la función de perseguir el delito y posteriormente en el juicio oral la de acusar, entre otras, siendo equivalente en los Estados esta figura, de inferior categoría.

La fase de investigación del proceso penal está en manos de la Policía, cuya actividad es instada por el Fiscal, quien comunica al Juez los hechos una vez el sospechoso es detenido, iniciándose el proceso por regla general, dadas las diferencias entre las legislaciones, con una audiencia preliminar contradictoria o comparecencia previa al juicio (Preliminary Hearing), en la que normalmente el Fiscal, con base al material recogido por la Policía, debe convencer al Juez de la verosimilitud de comisión del hecho criminal por el encausado, siguiéndose adelante hacia el verdadero juicio acusando ya formalmente, o $\mathrm{no}^{59}$.

A la vista de estas consideraciones, qué opiniones dogmáticas y prácticas se han sustentado por una y otra posición. Veámoslas, ofreciendo al final nuestro parecer.

b) Los argumentos a favor y en contra de que instruya el Fiscal: Ante todo, y a la luz del artículo 117.3 CE, que otorga la potestad jurisdiccional de juzgar a los Jueces, y del art. 124.1 CE, que concede al Ministerio Fiscal la misión de promover la acción de la Justicia en defensa de la legalidad y del interés público tutelado por la Ley, la primera cuestión que se plantea en España es si sería constitucional atribuir la investigación del delito a la Fiscalía. Se trata en suma de analizar si el «juzgar» comprende el «instruir» o no. Decidida, en su caso, su constitucionalidad, cuestión distinta, que también abordaré al final, es su conveniencia en estos momentos.

Aunque me voy a centrar en ello, enumeraré brevemente antes los argumentos más importantes que con carácter general se han formulado a favor y en contra de que instruya el Fiscal, pues ha habido muchos y de muy distinto signo, para que el lector tenga un mejor conocimiento del tema ${ }^{60}$ :

Leading Supreme Court Cases and Introductory Text, Thomson-West, St. Paul MINN 2011, págs. 44 a 46. Traducida al español como Israel, J.H. / Kamisar, Y. / Lafave, W.R. / KInG, N.J., Proceso Penal y Constitución de los Estados Unidos de Norteamérica. Casos destacados del Tribunal Supremo y Texto Introductorio, JuAN-Luis Gómez ColOMER (Director de la traducción), Tirant lo Blanch, Valencia 2012, págs. 44 a 46. También, Gómez CoLOMER, J.L. (Coord.), Introducción al Proceso Penal Federal de los Estados Unidos de Norteamérica, cit., págs. 158 y ss.

59 Véanse Weigend, TH., „Funktion und Tätigkeit der Staatsanwaltschaft in den U.S.A.«, en JESCHECK / LeIBINGER, Funktion und Tätigkeit der Anklagebebörden im ausländischen Recht, Nomos, Baden-Baden 1979, págs. 587 y ss.; SCHMID, N., Das amerikanische Strafverfahren. Eine Einführung, C.F. Müller, Heidelberg 1986, págs. 36 y ss.; y FANCHIOTTI, V., Lineamenti del processo penale statunitense. Corso di Lezioni, Giappichelli, Torino s/f, págs. 68 y ss. Aspectos concretos en Esparza Leibar, I., El principio del proceso debido, J.M. Bosch, Barcelona 1995, págs. 91 y 92.

60 Me remito por tanto a Gómez Colomer, J.L., «La instrucción del proceso penal por el Ministerio Fiscal...», cit., págs. 481 y ss. 
$1^{\circ}$ ) Argumentos a favor de que instruya el Juez:

a) La instrucción es oficio de Juez, no de parte, y encomendársela al Fiscal es un contrasentido y una incoherencia, además de un error, porque en el proceso penal la instrucción no se agota en la búsqueda de las pruebas, sino que se extiende también a una valoración finalista, «lo cual postula en el instructor la imparcialidad del Juez, no la parcialidad de la parte». Detener al imputado, ordenar su ingreso en prisión o puesta en libertad, practicar anticipadamente la prueba, etc., son manifestaciones típicas de ejercicio de la potestad jurisdiccional. Otorgar facultades instructorias al Ministerio Fiscal significaría una quiebra del principio «ne eat iudex ex officio», porque el Fiscal se convertiría así al mismo tiempo en juez y parte.

b) En esa línea se añade que la fase de investigación no sólo entraña actos de investigación, sino también enjuiciamientos jurídicos, como la inadmisión de la querella, o la imposición de medidas cautelares, absolutamente entrelazados entre sí, por lo que su escisión sería perturbadora para los fines del proceso penal, con lo que debe seguir en manos del Juez.

c) La dependencia del Ministerio Fiscal respecto al Poder Ejecutivo, antes mencionada, sería peligrosísima para una investigación objetiva e imparcial, al menos en los casos en que estuvieran implicados altos cargos y políticos.

d) El art. $117 \mathrm{CE}$ atribuye en exclusiva a los Jueces la función jurisdiccional, por lo que la instrucción a cargo del Fiscal sería en España inconstitucional (sobre ello, v. inmediatamente).

e) Trasladar la competencia para la instrucción al Fiscal conllevaría no pocos inconvenientes prácticos, por lo que es mejor dejarla como está, en manos del Juez: De facto instruiría la Policía Judicial, habría disminución de garantías para el imputado, a pesar de todo sería necesario un Juez, en España tenemos pocos fiscales, existen muchas carencias funcionales, hay peligro de impunidad para personas «gubernamentales», etc., argumentos que han sido puestos de manifiesto por los propios jueces y fiscales, y por la doctrina, todos ellos absolutamente reales, que nada tienen que ver con desconfianza hacia el Fiscal u opiniones subjetivas parecidas, utilizados con diferente finalidad por determinados autores, fundamentalmente prácticos.

\section{$\left.2^{\circ}\right)$ Argumentos a favor de que instruya el Fiscal:}

a) Los antecedentes históricos en todos los países que han conocido el sistema inquisitivo juegan en contra del Juez, porque al instruir y fallar en él ese mismo Juez, se le relaciona con el poder dictatorial o autoritario. Dogmáticamente la solución es que se evolucione o cambie hacia el sistema adversarial (acusatorio), en el que instruye el Fiscal. La reforma es muy tentadora cuando el país acaba de pasar de un régimen dictatorial, en el que han colaborado probadamente 
los jueces, a un régimen democrático, como ha ocurrido en España y en prácticamente toda América Latina.

b) También es más fácil cuando, siendo el proceso penal acusatorio, mixto o no, la Justicia no funciona, pues la instrucción a cargo del Fiscal aparece como una de las alternativas que tan ansiosamente se buscan para reducir la carga de los órganos jurisdiccionales, principal causa del mal funcionamiento de la Justicia, y acelerar el proceso penal, dada la reiteración de actuaciones, por un lado, las practicadas por el Fiscal y la Policía, y por otro, las mismas generalmente, las del Juez.

c) Finalmente, es asímismo fácil de admitir, como hemos visto, cuando el propio Ministerio Público no depende del Poder Ejecutivo, como en Italia, o cuando el Ministerio Fiscal no tiene la consideración de parte formal en el proceso penal, como en Alemania, pues entonces está obligado a la Verdad y Justicia.

d) El argumento más importante a favor de que instruya el Ministerio Fiscal es, en nuestra opinión, que no puede ser la misma persona la que considere necesario un acto de instrucción y la que valore su legalidad. En esencia el argumento se concreta de la siguiente manera: El Ministerio Fiscal debe asumir la instrucción, atribuyéndole el poder de investigar el delito, mientras que el Juez debe quedar como controlador de la legalidad de los actos procesales que ha realizado el Fiscal, generalmente a través de la resolución de peticiones y de los recursos. Seguir manteniendo el sistema clásico es en definitiva una contradicción, porque el Juez es al mismo tiempo quien investiga y quien garantiza el respeto de los derechos del imputado. Cambiar estos papeles puede significar ciertamente una importante restricción del principio de investigación oficial, pero se fortalece extraordinariamente el más importante principio de la imparcialidad judicial, que queda así únicamente reservado para el enjuiciamiento, lo que implica además una mejor aplicación del principio de la exclusividad de la función jurisdiccional por su único titular, el Poder Judicial.

Nuestra opinión: Pues bien, expuestos estos argumentos volvamos a la cuestión más relevante. La idea central que exponen quienes defienden la inconstitucionalidad del otorgamiento de la instrucción a cargo del Fiscal, se basa en que el art. 117 de la Constitución española de 1978 atribuye en exclusiva a los Jueces la función jurisdiccional, entendiendo que los actos de instrucción son actividad jurisdiccional, porque toda investigación requiere una valoración jurídica, sin perjuicio de muchos actos concretos que son indubitadamente actos de Juez, como la imposición de medidas cautelares o la prueba anticipada, que se practican en la fase preparatoria del juicio, luego si esas diligencias de investigación son actividad judicial, sólo el Juez puede ser competente para acordarlas, por lo que la instrucción a cargo del Fiscal sería en España inconstitucional.

En definitiva, como ponen de manifiesto autores significados con profusión de argumentos teóricos y prácticos, el art. 117.3 CE, al otorgar a los Jueces y Magistrados en exclusiva la titularidad de la potestad jurisdiccional, y no siendo el Ministerio Fiscal órgano jurisdiccional, veta la posibilidad de que se le puedan 
conceder a éste poderes en la instrucción que sean inherentes al ejercicio de la potestad jurisdiccional misma ${ }^{61}$.

Por contra, los defensores de su constitucionalidad alegan:

$1^{\circ}$ ) En primer lugar, que el sumario tiene naturaleza administrativa, luego el órgano competente para formarlo ha de ser administrativo y no judicial ${ }^{62}$, añadiendo que existe una profunda contradicción entre el significado conceptual de la palabra «Juez»y sus funciones, porque instruyendo no juzga, y porque, sobre todo, queda encuadrado dentro de un estatuto orgánico y dentro de un Poder del Estado, el Judicial, que no le corresponde, ya que no siendo juicio la instrucción, la investigación de un crimen es actividad administrativa y no judicial, en el sentido referido a Justicia ${ }^{63}$. Por tanto, el Juez debe limitarse a ejercer la función jurisdiccional, es decir, a juzgar, no a instruir, y eso solamente se produce en el juicio oral de acuerdo con la Constitución ${ }^{64}$. La cuestión central es así que durante la fase de investigación del proceso penal no se ha ejercido todavía la acción penal.

$2^{\circ}$ ) Por otro lado, se afirma que la instrucción por parte del Juez es incompatible con el modelo de proceso acusatorio que sustenta nuestra Constitución ${ }^{65}$.

61 Véase, destacadamente, Ortells Ramos, M., «Nuevos poderes para el Ministerio Fiscal en el proceso penal: Límites constitucionales y valoración político-jurídica», Revista de Derecho Procesal 1990, núm. 2, págs. 236 y ss.

62 Véanse Serra Domínguez, M., «El Ministerio Fiscal», Revista de Derecho Procesal Iberoamericana 1979, págs. 644 y 645; del mismo autor, «La instrucción de los procesos penal y civil: El sumario», en Estudios de Derecho Procesal, Ariel, Barcelona 1969, págs. 723 y 724. Sobre la naturaleza jurídica del sumario y la posición del Fiscal, v. PASTOR López, M., El proceso de persecución. Análisis del concepto, naturaleza y específicas funciones de la instrucción criminal, Universidad, Valencia 1979, págs. 59 a 72, y 152 a 155.

63 Véase Vives Antón, T.S., «Comentarios a la Ley de Medidas...», cit., vol. II, pág. 117.

64 Véanse Vives Antón, T.S., «Doctrina constitucional y reforma del proceso penal», Revista Poder Judicial, núm. especial II, págs. 101 y 102; y Ruiz VADILlO, E., «La actuación del Ministerio Fiscal en el proceso penal», Revista Poder Judicial, núm. especial II, págs. 84 a 87.

65 Pero esta segunda opinión, procedente del Derecho comparado, basada en el principio acusatorio, nos parece más endeble, pues al menos con referencia a España, entendido en sentido riguroso, el principio acusatorio sólo debe significar estas tres cosas: Todo proceso penal requiere de una acusación formulada por persona distinta al órgano judicial que ha de sentenciar, la imposibilidad de alterar el objeto del proceso condenando por hechos distintos a los acusados o a persona distinta a la acusada, y, finalmente, se permite, por no afectar a su imparcialidad, que el juzgador pueda aportar de oficio pruebas al proceso, respetando los hechos punibles puestos de manifiesto por las partes, v. sobre esta cuestión MonTEro ArocA, J., «La garantía procesal penal y el principio acusatorio», Revista La Ley 1994, t. I, págs. 979 a 983; y, del mismo autor, «El principio acusatorio. Un intento de aclaración conceptual», Revista Justicia 1992, núm. IV, págs. 781 a 786. Con carácter general, v. Armenta Deu, T., Principio acusatorio y Derecho Penal, J.M. Bosch e Instituto de Criminología, Barcelona 1994, págs. 39 y ss.; Asencio Mellado, J.M., Principio acusatorio y derecho de defensa en el proceso penal, Trivium, Madrid 1991, págs. 14 y ss.; Idem, «Principio acusatorio: Realidad y utilización (lo que es y lo que no es)», Revista de Derecho Procesal 1996, vol. 2, págs. 265 y ss.; De Diego DíEz, L.A., «El principio «el que instruye no debe juzgar» como garantía de imparcialidad en el enjuiciamiento penal», Revista Poder Judicial 1987, núm. 8, págs. 9 y ss.; Idem, «El derecho a la tutela judicial efectiva en la sentencia penal. Los principios acusatorio y de contradicción», Revista Justicia 88, vol. I, págs. 103 y ss.; De La Oliva Santos, A., «Disponibilidad del objeto, conformidad del imputado y vinculación del Tribunal a las pretensiones en el proceso penal», Revista General del Derecho 1992, págs. 9853 y ss.; DE VEGA RUIZ, J.A., Proceso penal y derechos fundamentales desde la perspectiva jurisprudencial, Colex, Madrid 1994, págs. 131 y 
$3^{\circ}$ ) Se dice también, finalmente, que la instrucción por el Fiscal refuerza el principio político angular de la actuación jurisdiccional, la imparcialidad judicial, protegida constitucionalmente en el propio art. 117.1 de la Constitución, en los siguientes términos: No puede ser la misma persona la que considere necesario un acto de instrucción y la que valore su legalidad, argumento clave antes comentado $^{66}$.

En mi opinión no sería inconstitucional en España que instruyera el Fiscal, porque estoy de acuerdo con quienes piensan que el art. 117.3 de la Constitución, al definir la función jurisdiccional, según terminología clásica española, como «juzgar y hacer ejecutar lo juzgado», atribuyéndola en exclusiva a los órganos jurisdiccionales, lo que está pidiendo en realidad al legislador ordinario es que, en sentido estricto, la decisión de condenar o absolver a un acusado, con todos los actos que la fundamentan (prueba), la tome un juez, pero no impide que para

ss.; Delgado Martín, J., «Principio acusatorio y juicio de faltas», Revista Actualidad Penal 1995, vol. I, apartado VI; Díaz Cabiale, J.A., Principios de aportación de parte y acusatorio: La imparcialidad del Juez, Comares, Granada 1996, págs. 191 y ss.; Gimeno Sendra, J.V., «El juez imparcial en la doctrina del Tribunal Constitucional», en Poder Judicial, núm. esp. VI, págs. 267 y ss.; Martínez Arrieta, A., La nueva concepción jurisprudencial del principio acusatorio, Comares, Granada 1994, págs. 24 y ss.; Idem, «Principio acusatorio: Teoría general y aplicación práctica», en Cuadernos de Derecho Judicial: Los principios del proceso penal, Consejo General del Poder Judicial, Madrid 1992, págs. 51 y ss.; Mendizábal Allende, R., «La posición procesal del Ministerio Fiscal en la fase de investigación del proceso penal: de órgano inspector de la formación del sumario a órgano de investigación», en Estudios Jurídicos - Ministerio Fiscal 1999 - IV, págs. 35 y ss.; MoNtero Aroca, J., Principios del proceso penal. Una explicación basada en la razón, Tirant lo Blanch, Valencia 1997, págs. 16 y ss.; Idem, Sobre la imparcialidad del Juez y la incompatibilidad de funciones procesales, Tirant lo Blanch, Valencia 1999, págs. 39 y ss.; Ortells Ramos, M., «Correlación entre acusación y sentencia: Antiguas y nuevas orientaciones jurisprudenciales», Revista Justicia 91, págs. 529 y ss.; Idem, «Principio acusatorio, podres oficiales del Juzgador y principio de contradicción. Una crítica de cambio jurisprudencial sobre correlación entre acusación y sentencia», Revista Justicia 91, págs. 775 y ss.; Planchadell Gargallo, A., El derecho fundamental a ser informado de la acusación, Tirant lo Blanch, Valencia 1999, págs. 59 y ss.; PoLO RodrígueZ, J.J., «El Fiscal investigador e instructor», Estudios Jurídicos - Ministerio Fiscal 1997 - VI, págs. 11 y ss.; Romero Coloma, A.M., «Alcance de los principios del proceso penal español a la luz del ordenamiento constitucional», Revista Actualidad Penal 1995, vol. I, apartado XXI; Ruiz VAdillo, E., «Algunas desviaciones del sistema acusatorio y la Ley de Enjuiciamiento Criminal», Revista General del Derecho 1957, núm. 150, págs. 207 y ss.; Idem, «Algunas breves consideraciones sobre el sistema acusatorio y la interdicción constitucional de toda indefensión en el proceso penal», Revista La Ley 1987, núm. 4, págs. 873 y ss.; Idem, El principio acusatorio y su proyección en la doctrina jurisprudencial del Tribunal Constitucional y Tribunal Supremo, Actualidad Editorial, Madrid 1994, págs. 139 y ss.; Idem, «El principio acusatorio», Revista del Ministerio Fiscal 1995, núm. 1, págs. 89 y ss.; Idem, Estudios de Derecho Procesal Penal, cit., págs. 57 y ss.; SAavedra Ruiz, J., «La iniciativa del Tribunal en el acto del juicio oral. Alcance de los artículos 729 y 733 LECRIM», en Cuadernos de Derecho Judicial: Cuestiones de Derecho Procesal Penal, Consejo General del Poder Judicial, Madrid 1994, págs. 13 y ss.; VÁzQUez Sotelo, J.L., «El principio acusatorio y su reflejo en el proceso penal español», Revista Jurídica de Cataluña 1984, núm. 2, págs. 93 y ss.; Verger Grau, J., La defensa del imputado y el principio acusatorio, J.M. Bosch, Barcelona 1994, págs. 15 y ss.; y las opiniones del constitucionalista López Aguilar, J.F., La Justicia y sus problemas en la Constitución, Tecnos, Madrid 1996, págs. 220 y 221. Pero sigue siendo válido el pensamiento sobre la acción penal de Gómez Orbaneja, E., Comentarios a la Ley de Enjuiciamiento Criminal, Bosch, Barcelona 1951, t. II, págs. 447 y ss.; v. también FAIRÉN GUILLÉN, V., «La disponibilidad del derecho a la defensa en el sistema acusatorio español», en Temas del Ordenamiento Procesal, t. II, Tecnos, Madrid 1987, págs. 1205 y 1206.

66 Véase Vives Antón, T.S., «Doctrina constitucional...», cit., pág. 102. 
llegar a la decisión de si se puede abrir el juicio oral contra una persona se acuda a personas y normas no sometidas al Derecho Jurisdiccional, lo que por cierto siempre ha ocurrido en la práctica aunque bajo el manto judicial.

Por tanto, que una futura LECRIM otorgue la instrucción del proceso penal al Ministerio Fiscal sería para mí constitucional, porque instruir no es juzgar.

Ahora bien, los temas relacionados con el Poder Judicial y ese instrumento necesario que es el proceso penal son siempre relativos, en el sentido de que se aplican a un país en un momento concreto. Tengo muy claro el tema de la constitucionalidad, pero otra cosa muy distinta es si es conveniente que instruya hoy, lo que ya no lo tengo tanto. ¿Qué es mejor, pues, en España a principios de 2018, que instruya las causas penales el Ministerio Fiscal, o que las siga instruyendo la autoridad judicial?

Creo sinceramente que no ha llegado todavía el momento de emprender el cambio y que es mejor que las cosas sigan como están, al menos en tanto en cuanto no se cumplan los siguientes requisitos ${ }^{67}$ :

a) Mientras, como consecuencia de los arts. 2.1, 8, 29.1, 31.5, 36.1, 67.3, 72 y DA-2 $2^{a}$ EOMF, se siga opinando fundadamente que el Fiscal no es un órgano independiente en España, al poder quedar vinculado a una orden del Poder Ejecutivo, o se patentice su vinculación con éste por la práctica de esas normas; y

b) Mientras el Ministerio Fiscal tenga como principal función en el proceso penal la de acusar, oficio de parte, por tanto, no sea imparcial en sentido jurídico estricto; y

La tutela de los derechos fundamentales y procesales penales ordinarios de los ciudadanos debe seguir estando residenciada en manos de los Jueces, porque con su independencia e imparcialidad, esenciales a su función, realizan una labor más efectiva, aspecto en cuanto a los derechos ordinarios al menos, que no queda mejor garantizado en absoluto si instruyen los Fiscales.

Ello, sin entrar ahora en la cuestión estadística de si hay en España suficiente número de Fiscales para afrontar tan radical cambio. Y, obsérvese, si instruye el Fiscal, sigue siendo necesario un Juez de la Libertad, como dicen los italianos, para tomar las decisiones que afecten a los derechos y garantías fundamentales del imputado, y, en suma, a actividad jurisdiccional.

Lo que desde luego no tiene ningún sentido es que en unos casos instruya el Juez y en otros el Fiscal, como en España.

Nos mantenemos, pues, en nuestra opinión expresada hace ya muchos años ${ }^{68}$, insistiendo ahora, para finalizar, en que en el fondo este tema nos parece de los menos graves que tiene planteada la situación jurídico-procesal penal española en la actualidad. A nosotros lo que nos preocupa de verdad es que el proceso penal

67 Véanse las opiniones al respecto de Gimeno SENDRA, J.V., «Algunas sugerencias sobre la atribución al Ministerio Fiscal de la investigación oficial», Revista Justicia 1988, núm. IV, págs. 832 a 834.

68 Véase Gómez Colomer, J.L., «No es conveniente que nos pueda procesar un fiscal», Jueces para la Democracia 1987, núm. 2, pág. 10. 
español sea el propio de un Estado de Derecho, y al respecto todavía no hemos llegado al $100 \%$ exigible, aunque hemos avanzado mucho sin duda en España, pero ésta es otra cuestión que ahora no puede abordarse ${ }^{69}$.

\section{CONCLUSIONES.}

Dos son los temas que he tratado aquí y, por tanto, dos son las conclusiones a sentar:

$1^{\text {a }) ~ S i ~ s e ~ i n s t a u r a ~ e l ~ s i s t e m a ~ a d v e r s a r i a l ~ d e ~ e n j u i c i a m i e n t o ~ c r i m i n a l, ~ e l ~ F i s c a l ~}$ en España debe ser un órgano constitucional político, dependiente del Ministerio de Justicia, pero organizado con carácter autónomo, de manera que pueda constituirse en una administración propia, sujeta a los principios de unidad de actuación, dependencia jerárquica, legalidad, imparcialidad y objetividad. El acusado debe saber en todo momento que es el Gobierno, a través del Fiscal, quien le está exigiendo responsabilidad penal por sus actos. En caso de que no se instaure o hasta que ese sistema llegue, lo mejor es dejar las cosas como están, pero sin engañar a nadie, pues el Fiscal, en los términos expuestos en este escrito, es en mi humilde opinión políticamente dependiente del Gobierno.

$2^{\mathrm{a}}$ ) El Fiscal no debe instruir las causas penales si se mantiene el sistema acusatorio formal o mixto actual, por las razones coyunturales expuestas, de carácter organizativo, estructural y práctico. Si se instaura el sistema adversarial, el Fiscal, quien ostenta en régimen de monopolio (exclusividad) la titularidad de la acción penal, necesariamente debe instruir el proceso penal, y mucho más allá, lo que hoy por hoy representaría costos políticos inasumibles en España, deben desaparecer la acción particular y la acción pública (previstas en la Constitución), así como ha de potenciarse el poder investigador de la Policía Judicial hasta niveles insospechados.

La envergadura de estas modificaciones, por muchos matices locales que queramos introducir, aconseja que, en vez de un cambio radical hacia lo adversarial, hagamos una evolución propia que nos permita compararnos con los países más avanzados, como hizo Alemania en 1975, sin destruir nuestra historia legal ni nuestros valores propios.

Este progreso legal avanzando desde nuestras propias raíces, dejándonos influir por el Derecho comparado sólo en lo que valga la pena y rechazando cualquier copia o imposición, permitiría una evolución más sosegada y la fijación de un «nuevo» sistema de enjuiciamiento criminal mucho mejor que el actual, resolviéndose el problema de la autonomía funcional del Ministerio Fiscal en el

69 Prueba de ello es que, por poner sólo un ejemplo, acceder al amparo constitucional en materia de derechos fundamentales aplicables al proceso penal es cada vez más difícil para las partes, ante los casi insuperables requisitos de admisión de la demanda que exige el art. 50.1, b) de la Ley Orgánica del tribunal Constitucional de 1979 (modificado en 2007). 
proceso penal, así como la garantía de su objetividad, y si debe instruir el proceso penal, conforme a las exigencias sociales del momento.

Esta reforma evolutiva, a la vista de la penosa situación actual, no puede aplazarse más tiempo.

TITLE: The spanish public prosecution service: should it be an independent institution?

AbSTRaCt: The Spanish Public Prosecution Service has, foremost, a problem of organic identity. It is believed that it should be independent from the Government, but the laws confirm some degree of dependence. The Public Prosecution should depend on the Government if the reform toward an adversarial model of criminal procedure is pursued, because that is the nature that best fits a system in which the defendant knows he is facing an Administration that, fulfilling its public duty, is demanding with all its powers that he takes responsibility for his actions. Until the change is produced, it is better to leave things as they are. The Public Prosecution Service should not direct the criminal investigation while the foresaid adversarial system in not in force in Spain. If it did, it would be constitutional, but it has not been demonstrated that it is ready to do so and, probably, in spite of official declarations, the Public Prosecution does not want now to assume that responsibility. With the current laws and practices, the Prosecution Service would be in danger of being taken as a non-objective organ in the most important cases.

Resumen: El Ministerio Fiscal español tiene ante todo un problema de identidad orgánica. Se desea que sea independiente del Gobierno, pero las normas confirman una cierta dependencia. El Ministerio Fiscal debe ser dependiente del Gobierno si se consuma la reforma hacia un modelo adversarial de enjuiciamiento criminal, porque ésa es la naturaleza que mejor cuadra con dicho sistema, en donde el acusado sabe que enfrente tiene a la Administración, que, cumpliendo con su deber público, le exige con todo su poder responsabilidad por sus actos. Hasta que se produzca el cambio, es mejor dejar las cosas como están. El Ministerio Fiscal no debe instruir el proceso penal ni dirigir la investigación del crimen mientras no tengamos el antedicho sistema adversarial vigente en España. Sería constitucional si lo biciera, pero no está probado que esté preparado para bacerlo, y probablemente, a pesar de declaraciones oficiales, no desee asumir abora esa responsabilidad. Con las normas y la práctica actual, correría el peligro de ser visualizado en los casos más importantes como un órgano no objetivo.

Key words: Public Prosecution Service, Relationship with the Government, Criminal Procedure, Criminal Investigation Director.

Palabras Clave: Ministerio Fiscal, Relación con el Gobierno, Proceso Penal, Órgano instructor y dirección de la investigación del crimen.

FECHA DE RECEPCIÓN: 13.01.2018 FeCHA DE ACEPTACIÓN: 01.02.2018 